Article

\title{
Effects of Vegetation Management on Wood Properties and Plant Water Relations of Four Conifer Species in the Pacific Northwest of the USA
}

\author{
Joyce Aernouts ${ }^{1}$, Carlos A. Gonzalez-Benecke ${ }^{2, *(1)}$ and Laurence R. Schimleck ${ }^{3}$ \\ 1 Laboratory of Wood Technology, Ghent University, 9000 Ghent, Belgium; joyce_aernouts@hotmail.com \\ 2 Department of Forest Engineering, Resources and Management, Oregon State University, Corvallis, \\ OR 97331, USA \\ 3 Department of Wood Science and Engineering, Oregon State University, Corvallis, OR 97331, USA; \\ laurence.schimleck@oregonstate.edu \\ * Correspondence: carlos.gonzalez@oregonstate.edu; Tel.: +1-541-737-2103
}

Received: 5 May 2018; Accepted: 31 May 2018; Published: 4 June 2018

\begin{abstract}
In plantation forests, competition from unwanted vegetation may reduce survival and negatively impact tree growth. The goal of this study was to examine the influence of vegetation management treatments on plant water relations and wood properties. Control trees (no treatment) were compared to trees subjected to post-planting competing vegetation control for five consecutive years after planting. Four conifer species (Douglas-fir, western hemlock, western redcedar, and grand fir) were studied on two different sites in western Oregon, USA. Carbon isotope $\left({ }^{13} \mathrm{C}\right)$ analysis was used to study intrinsic water use efficiency (iWUE) and X-ray densitometry was used to measure specific gravity, ring width, and latewood percent. We found a significant interaction between vegetation management treatment and wood ring (growing season) in iWUE for Douglas-fir. There was little effect of vegetation management treatment on ring specific gravity for all species. Only western redcedar growing at a central Coast Range site showed increased ring specific gravity under sustained competing vegetation control. When growing under conditions of sustained control of competing vegetation, western redcedar at a central Coast Range site had a significant increase in earlywood specific gravity, while Douglas-fir at a Cascade Foothills site had a significant decrease in latewood specific gravity. Western redcedar and grand fir had a significant interaction-effect on its latewood percentage, with treatment trees having a higher latewood percentage than control trees after ring 8. Further, Douglas-fir and western hemlock had a significant increase in ring, earlywood, and latewood area with treatment, and grand fir had a significant interaction-effect of treatment $x$ ring for ring, earlywood, and latewood area. This study indicates that, for conifer trees growing under sustained vegetation control, growth gains could be achieved without compromising wood properties. However, if harvested at a target diameter, these trees will have a larger proportion of low quality corewood compared to trees from conventionally managed stands.
\end{abstract}

Keywords: competing vegetation control; intensive silviculture; wood specific gravity; carbon isotope discrimination: water use efficiency; Douglas-fir; grand fir; western hemlock; western redcedar

\section{Introduction}

Forests in the U.S. Pacific Northwest (PNW) are highly productive and dominated by long-lived conifers species [1]. Because the PNW region exceeds more than 20 degrees in latitude and has many elevation differences, species composition varies depending on location and as a result of changing temperatures and moisture [2]. Douglas-fir (Pseudotsuga menziesii (Mirbel) Franco) (DF) is 
frequently identified with PNW forests and is the most commonly grown commercial species. DF is very adaptable and thrives in many environments. It can survive in full sun as well as shade and likes a moist, but well-drained soil. It grows best in areas with both hot summers and cold winters, and can be sensitive to strong winds. Western hemlock (Tsuga heteophylla (Raf.) Sarg.) (WH) is its most common associate and replaces DF in climax forests. WH prefers rain and fog and is generally found in temperate rainforests close to the coast from northern California to south-eastern Alaska and west to the northern Rocky Mountains. Another common species, western redcedar (Thuja plicata Donn ex D. Don) (WRC), is typically found on wet, poorly drained sites, but it can occur on dry slopes. The commercial range is the coastal fog belt and Cascades piedmont, but its native range extends from northern California to Alaska, and from the Pacific Ocean to Montana. At higher elevations (up to 1500 m.a.s.l.) Grand fir (Abies grandis (Douglas ex D. Don) Lindl.) (GF) is common it prefers moist locations, and is very shade tolerant [3].

After a disturbance such as harvest or fire, site resources are readily available and early seral species will rapidly use those resources and occupy the site. Competition from spontaneous vegetation can reduce tree survival and negatively impact growth of planted DF, as well as other PNW conifer species [4]. Forest vegetation management (FVM) is an integral part of reforestation in the PNW. FVM reduces the amount of competing vegetation so that site resources such as soil moisture and nutrients are readily available for growing trees, thus ensuring a more successful re-establishment of forest cover after a disturbance such as harvest or fire. Various methods are used to control unwanted vegetation, including machine removal, manual slashing, broadcast burning, and herbicides [5]. In the PNW, and in other parts of the world, the most common FVM method has been herbicide application owing to its effectiveness in temporarily reducing the amount of competing vegetation and increasing seedling growth and survival [6-8]. Studies have also shown that 2-3 years after herbicide treatments, there are no adverse effects on understory species richness and diversity $[9,10]$.

Vegetation management regimes common to the establishment of managed DF plantations can restrain competing vegetation, improve planted seedlings growth, and maintain diverse vegetation communities on multi-year timescales. Dinger and Rose (2010) [11] reported that the improvement of growing conditions during the first two years of establishment with intensive vegetation control enabled seedlings to continue vigorous growth beyond chemical persistence. Rose et al. (2006) [8] found that two years of herbaceous vegetation control combined with three years of woody control could substantially increase volume growth in DF through Year 12. The preharvest vegetation community present on a site had a strong influence on the possible presence of competitive woody species, thereby influencing the response to vegetation management practices. Goracke (2010) [12] found that the control of competing vegetation during the critical years of stand development increased the growth of DF and WRC in western Oregon plantations. Giving seedlings access to site resources for several years during establishment offers them an advantage over the competing vegetation needed to rapidly occupy the site, closing canopy sooner and increasing stem volume growth. Lastly, Chen (2004) [4] studied the effect of vegetation management on the growth of DF, WH, WRC, and GF in four western Oregon sites. Stem diameter increased and the height/diameter ratio was stable. Conifer seedling growth was improved after vegetation control, but the third- or fourth-year survival was mostly unaffected by herbicide treatment.

The positive growth response can be attributed, at least in part, to increased soil moisture availability, and thus, reduced plant water stress. When a plant is experiencing water stress, it will close its stomata to minimize water loss, and as a consequence, limit carbon dioxide uptake. Because of stomata aperture control, there is a strong link between water loss and carbon uptake, expressed via the intrinsic water use efficiency (iWUE) [13]. The carbon isotopic ratio $\left(\delta^{13} \mathrm{C}\right)$, which varies in response to varying environmental conditions, can then be used to calculate the iWUE, which is defined as the ratio of assimilated carbon over the stomatal conductance for water vapor [14].

Annual growth rings form in trees that have an annual pattern of growth followed by a dormant period. The proportions of earlywood (EW) and latewood (LW) within an annual ring are also 
influenced by water stress. The earlywood of the ring is formed early in the growing season and accounts for $40-80 \%$ of a ring's width. Latewood is formed later in the season when growth slows and eventually stops. The difference between these types of wood is the size of the cells and the thickness of the cell wall, which results in different densities for EW and LW, with LW having thicker cell walls, smaller lumen diameters, and greater mechanical strength $[15,16]$.

The ratio between EW and LW plays an important role in determining overall specific gravity (SG) the ratio of the density of wood (cell wall substance) to the density of pure water at $4{ }^{\circ} \mathrm{C}$, of wood in coniferous trees [17]. The amount of LW is associated with SG, mechanical strength, and pulp yield [18]. An increase in strength is attributed to a higher amount of thick walled, stronger LW cells in proportion to thin walled, weaker EW cells. A change in EW and LW growth patterns can reflect a change in environmental conditions such as water availability [15]. Temperature, sunlight conditions, and the local topography are also factors that can affect the width of tree rings and EW or LW amounts. Several studies have shown that drought stress during EW formation can cause a higher wood SG due to a greater proportion of LW. In periods with lower precipitation and lower temperatures during spring, EW growth decreases and the proportion of LW is higher. On the other hand, when growing conditions are optimal, EW growth is enhanced and the proportion of LW is reduced. When water availability is not limiting during LW formation, higher SG wood is produced due to extended growing season that produced more LW [19]. Barnett et al. (2003) [20] came to the same conclusion; increasing water availability can significantly increase the ratio of LW to EW of temperate-zone conifers by delaying the entry of the cambium into dormancy during cambial growth in mid- to late-summer.

Changes in intrinsic water use efficiency and wood properties in response to competing vegetation control have not been reported for PNW species. Hence, the aim of this study was to examine how four common PNW conifer species (DF, WH, WRC, and GF) growing on two sites in western Oregon, USA, responded to contrasting vegetation management treatments in terms of plant water status (iWUE) and wood properties (ring SG, EW SG, LW SG, and LW\%) and ring area growth.

\section{Materials and Methods}

\subsection{Study Sites}

Two different sites located in western Oregon, USA were chosen because they represent contrasting, but common, PNW working forests. The first study site is located in the central Coast Range (CR) near Summit, Oregon at $44^{\circ} 38^{\prime} 40^{\prime \prime} \mathrm{N}, 123^{\circ} 33^{\prime} 30^{\prime \prime} \mathrm{W}$. The site is characterized by fine loamy soil, with a water holding capacity of $199 \mathrm{~mm}$ in top $1 \mathrm{~m}$ of soil. The elevation is about $234 \mathrm{~m}$, the average precipitation is $1707 \mathrm{~mm} /$ year, with a mean annual temperature of $11.1{ }^{\circ} \mathrm{C}$. At this site, four conifer species were planted in January 2000 for the study: DF, WH, WRC, and GF. The second study site is located at the Cascade foothills (CF) near Sweet Home, Oregon at $44^{\circ} 28^{\prime} 32^{\prime \prime} \mathrm{N}$, $122^{\circ} 43^{\prime} 16^{\prime \prime} \mathrm{W}$. The site is characterized by silty clay loam soil, with a water holding capacity of $130 \mathrm{~mm}$ in the top $1 \mathrm{~m}$ of soil. The elevation is about $200 \mathrm{~m}$, the average precipitation is $1179 \mathrm{~mm} /$ year, with a mean average temperature of $12.4^{\circ} \mathrm{C}$. At this site only two species were planted in February 2001: DF and WRC. At both sites, styro-15 seedlings were planted. Both study sites were established and managed by the Vegetation Management Research Cooperative (VMRC) at Oregon State University.

A randomized complete-block experiment with eight treatments was established at both sites. Each plot is $24 \mathrm{~m} \times 24 \mathrm{~m}$ in size with 36 seedlings at a spacing of $3 \mathrm{~m} \times 3 \mathrm{~m}$, surrounded by a row of border trees planted from the same species. At the CR site, there are four replicates (blocks) of DF and WH, and three replicates of WRC and GF. At the CF site, all treatments had four replicates.

All plots (including control) on both sites received a fall site preparation herbicide application prior to planting in the winter. The eight different treatments were post-planting spring release applications that can be defined by the number and timing of herbicide treatments applied during the first 5 years after planting. Further details on treatment of the whole study can be found in 
Maguire et al. (2009) [7]. For this study, only the control (O) and the 5 consecutive years of spring release vegetation management treatment $(\mathrm{T})$ were used. Vegetation control was implemented to reduce competing vegetation cover below $25 \%$ throughout the season by applying a pre-planting (fall) herbicide treatment and several post-planting (spring) herbicide release treatments. On both sites, the herbicides applied for fall site preparation consisted of sulfometuron $(0.15 \mathrm{~L} / \mathrm{ha})$, metsulfuron (0.04 L/ha), and glyphosate ( $4.68 \mathrm{~L} / \mathrm{ha})$. Atrazine $(4.5-4.9 \mathrm{~kg} / \mathrm{ha})$ and clopyralid $(0.58-0.73 \mathrm{~L} / \mathrm{ha})$ were applied for the spring release treatments. If the spring release treatment failed to reduce weed cover to below 25\%, additional summer applications were conducted (glyphosphate 1.5-2.0\%).

\subsection{Carbon Isotope Analysis}

For carbon isotope analysis, samples were taken from tree disks obtained from biomass sampling performed by Flamenco et al. (2018) [21]. Four trees per treatment and species were sampled at each site, encompassing the range in diameter at breast height (DBH) found for each species at each site. A total of 48 trees were sampled (32 at the CR site and 16 at the CF site). Prior to the start of tree sampling, tree inventories were conducted in March 2016 (age 16 years at CR site, and 15 years at CF site.) Further details of the tree sampling can be found in Flamenco et al. (2018) [21]. At both sites, DF plots were thinned from below to reduce stocking by $20 \%$ at age 12 years. Table 1 summarizes stand characteristics in March 2016. In treated plots (T), trees were larger and had better survival, showing larger basal area (BA), quadratic mean diameter (QMD) and stem volume (VOB).

Table 1. Average trees per ha (TPHA, ha ${ }^{-1}$ ), basal area $\left(\mathrm{BA}, \mathrm{m}^{2} \mathrm{ha}^{-1}\right)$, quadratic mean diameter (QMD, $\mathrm{cm}$ ), and volume outside bark (VOB, $\mathrm{m}^{3} \mathrm{ha}^{-1}$ ) for 15-16-year-old Douglas-fir (DF), western hemlock (WH), western redcedar (WRC), and grand fir (GF) trees growing under contrasting vegetation management treatments on sites located in the Cascade foothills (CF; 15 years) and Coast Range (CR:16 years) of western Oregon (Data from Flamenco et al. 2018 [21]).

\begin{tabular}{|c|c|c|c|c|c|c|}
\hline Site & Species & Treatment & $\begin{array}{l}\text { TPHA } \\
\left(\mathrm{ha}^{-1}\right)\end{array}$ & $\begin{array}{c}\text { BA } \\
\left(\mathrm{m}^{2} \mathrm{ha}^{-1}\right)\end{array}$ & $\begin{array}{l}\text { QMD } \\
(\mathrm{cm})\end{array}$ & $\begin{array}{c}\text { VOB } \\
\left(\mathrm{m}^{3} \mathrm{ha}^{-1}\right)\end{array}$ \\
\hline \multirow{4}{*}{$\mathrm{CF}$} & \multirow{2}{*}{ DF } & $\mathrm{O}$ & 696 & 12.8 & 15.9 & 73.9 \\
\hline & & $\mathrm{T}$ & 710 & 21.6 & 20.2 & 139.6 \\
\hline & \multirow{2}{*}{ WRC } & $\mathrm{O}$ & 351 & 4.2 & 12.5 & 18.6 \\
\hline & & $\mathrm{T}$ & 935 & 14.4 & 15.9 & 64.9 \\
\hline \multirow{8}{*}{ CR } & \multirow{2}{*}{ DF } & $\mathrm{O}$ & 688 & 18.4 & 18.5 & 127.4 \\
\hline & & $\mathrm{T}$ & 696 & 23.6 & 20.8 & 169.7 \\
\hline & \multirow{2}{*}{ WH } & $\mathrm{O}$ & 868 & 13.7 & 18.4 & 44.1 \\
\hline & & $\mathrm{T}$ & 1025 & 33.1 & 27.8 & 124.8 \\
\hline & \multirow{2}{*}{ WRC } & $\mathrm{O}$ & 798 & 4.7 & 10.6 & 19.8 \\
\hline & & $\mathrm{T}$ & 967 & 17.9 & 20.6 & 83.2 \\
\hline & \multirow{2}{*}{ GF } & $\mathrm{O}$ & 927 & 11.1 & 16.7 & 29.8 \\
\hline & & $\mathrm{T}$ & 997 & 31.8 & 27.7 & 97.5 \\
\hline
\end{tabular}

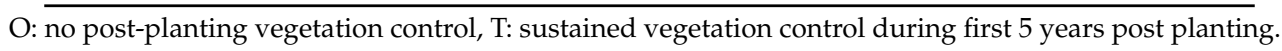

From each disk, four samples were taken. The first sample spanned growth rings 1 to 3 , the second rings 4 and 5, the third rings 6 to 8 , and the fourth rings 9 and 10. The first two samples (rings 1 to 5), correspond to xylem growth during treatment application period and the last two samples (rings 6 to 10), correspond to xylem growth after herbicide treatment. After separation into 4 sections, the samples were reduced to sawdust with a Dremel. A microbalance (Sartorius SE2 ultra, precision 0.0001) was used to weigh $850-900 \mu \mathrm{g}$. The samples were than analyzed in a mass spectrometer (Delta Plus-XL, Thermo Scientific, Dreieich, Germany) to measure the part carbon, $\delta^{13} \mathrm{C}$, expressed in $\% 0$ in regard to the standard VPDB (Vienna Pee Dee Belemninte). The calculation of iWUE is partly 
based on Brienen et al. (2010) [22]. $\Delta^{13} \mathrm{C}$, which expresses ${ }^{13} \mathrm{C}$-discrimination during carbon capture, is determined as:

$$
\Delta^{13} \mathrm{C}(\% 0)=\left(\delta^{13} \mathrm{C}_{\mathrm{a}}-\delta^{13} \mathrm{C}_{\text {cell }}\right) /\left(1+\delta^{13} \mathrm{C}_{\text {cell }} / 1000\right)
$$

in which $\delta^{13} C_{\text {cell }}$ is the value obtained by the carbon isotope analysis and $\delta^{13} C_{a}$ is the annual atmospheric $\delta^{13} \mathrm{C}$ value, averaged over the years corresponding with to analyzed growth rings. The $\delta^{13} C_{a}$ data is made available by Keeling et al. (2010) [23]. The Scripps Institution of Oceanography station "La Jolla" ( $\left.32^{\circ} 52.0^{\prime} \mathrm{N}, 117^{\circ} 15.5^{\prime} \mathrm{W}\right)$ was chosen because of its closest proximity to the study sites. With the annual $c_{a}[24]$, averaged over the years corresponding to the analyzed growth rings. The iWUE is determined as:

$$
\text { iWUE }=c_{a} \times\left(b-\Delta^{13} C\right) /(1.6 \times(b-a))
$$

The values for a and b, 4.4 and 27, respectively, were taken from McCarroll and Loader (2004) [25].

\subsection{Densitometry Analysis}

For the densitometry study, $12 \mathrm{~mm}$ diameter cores were taken using a Pressler borer. The cores were taken at a height of $0.30 \mathrm{~m}$ to capture as many growth rings as possible, especially the initial years of growth when treatments were applied. At each site 8 trees per treatment and species were sampled, giving a total of 96 samples to analyze with an X-ray densitometer (64 at CR site and 32 at CF site). Prior to analysis, a measure of basic density of each individual sample was necessary for calibration of the densitometer. Each core was cut in half at the pith and immediately after the sample was taken, the green volume was measured using the water displacement technique. Next the cores were conditioned, initially for 5 days in a $5{ }^{\circ} \mathrm{C}$ room and for the remaining time (4 weeks) in a $20{ }^{\circ} \mathrm{C}, 65 \% \mathrm{RH}$ room, giving the cores an approximate moisture content of $12 \%$. Basic density was calculated from the ratio of dry weight $(\mathrm{g})$ over green volume $\left(\mathrm{cm}^{3}\right)$. After conditioning, the samples were cut into radial strips (12 mm tangentially and $2 \mathrm{~mm}$ longitudinally) as described by Jordan et al. (2008) [26]. X-ray densitometry was conducted at USDA Forest Service Forestry Sciences Laboratory in Athens, Georgia using a QTRS-01X densitometer (Quintek Measurement Systems, Knoxville, TN, USA). The X-ray beam scanned the sample at $60 \mu \mathrm{m}$ intervals from bark to pith. Latewood specific gravity $\left(\mathrm{SG}_{\mathrm{L}}\right)$, earlywood specific gravity $\left(\mathrm{SG}_{\mathrm{E}}\right)$, ring specific gravity $\left(\mathrm{SG}_{\mathrm{R}}\right)$, latewood width $\left(\mathrm{W}_{\mathrm{L}}\right)$, earlywood width $\left(\mathrm{W}_{\mathrm{E}}\right)$, and ring width $\left(\mathrm{W}_{\mathrm{R}}\right)$ were measured during the analysis. $\mathrm{LW} \%$ was calculated for each ring as the percentage of latewood area to total growth ring area. For WRC, a specific gravity value of 0.425 was used to distinguish earlywood from latewood, while for the other species a value of 0.450 was used. Whole-ring $\mathrm{SG}_{\mathrm{R}}, \mathrm{SG}_{\mathrm{E}}$ and $\mathrm{SG}_{\mathrm{L}}$ were determined for each ring as the sum of the product of each wood property trait (earlywood and latewood) by the corresponding early- or latewood ring area and divided by total whole-ring area. To study the effect of treatment on the whole-tree, a weighted whole-tree value was determined for each individual tree, which was then used to calculate an average whole tree value for each species. Weighted whole-core $\mathrm{SG}_{\mathrm{R}}, \mathrm{SG}_{\mathrm{E}}, \mathrm{SG}_{\mathrm{L}}$ and $\mathrm{LW} \%$ were computed as the sum of the product of each wood property trait on each ring (earlywood and latewood) by corresponding ring area and divided by total tree cross section area [27].

For each site, monthly values of rainfall and Palmer drought severity index (PDSI; Palmer 1965 [28]) were obtained from Abatzoglou et al. (2017) [29] (West Wide Drought Tracker, https://wrcc.dri.edu/ $w w d t /)$. Even tough total yearly rainfall was always larger at the CR site, rainfall during period May to September (growing period) was similar across sites (Figure 1a). On average, between years 2000 and 2010, yearly rainfall at the CR and CF sites was 1619 and $1346 \mathrm{~mm}^{-1}{ }^{-1}$, respectively. During the same years, rainfall during growing period (May to September) averaged 192 and $221 \mathrm{~mm}$, at the CR and CF sites, respectively. Negative values of PDSI indicate that the site experienced a period of water deficit. The CR site experienced "moderate" to "low" drought during period May to September (PDSI > -2 ), on growing seasons 1, 3, 6, 8 and 9, while the CF experienced those levels of drought during growing 
seasons 5, 6, 9 and 10 (Figure 1b). The CR site experienced a severe drought during growing season 2 (year 2001), while the CF site had low PDSI during growing seasons 1, 2 and 3 (years 2001, 2002 and 2003).
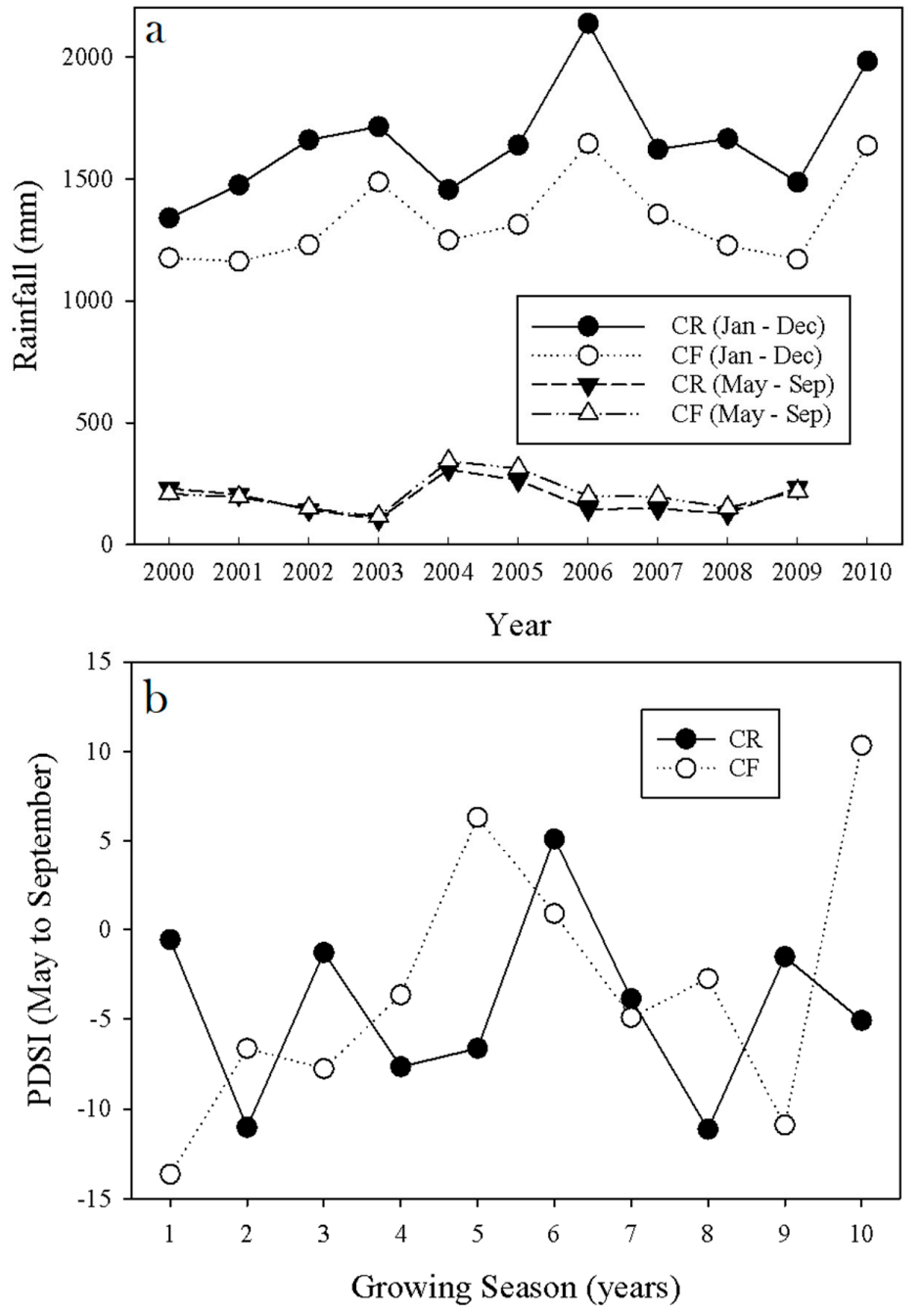

Figure 1. (a) Yearly rainfall and (b) Palmer drought severity index (PDSI) during growing period (between May and September) at the coast range site (CR, line with filled symbols) and the cascade foothill site (CF, line with open symbols) from 2000 to 2010. At the CR site, growing season 1 started in year 2000. At the CF site, growing season 1 started on year 2001.

\subsection{Statistical Analysis}

ANOVA was used to analyze effects in iWUE and wood property traits of VM and species, including Bonferroni adjustments for differences in least square means (PROC MIXED; SAS Inc., Cary, NC, USA). Repeated measures analysis was used to analyze time series data. Several covariance structure models were used for the time series analysis and the model with the lowest Schwartz's Bayesian information criterion was selected for each variable analyzed [30].

\section{Results}

\subsection{Intrinsic Water Use Efficiency (iWUE)}

A cross species comparison showed that all four species had a different intrinsic water use effieciency (iWUE), and the difference between $\mathrm{O}$ and $\mathrm{T}$ trees varied among species. On average, at both sites, WRC showed the largest iWUE $(p<0.001)$, followed by DF, WH and GF, averaging 101.8, 
92.7, 87.8 and $65.2 \mu \mathrm{mol} \mathrm{CO} \mathrm{Cmol} \mathrm{H}_{2} \mathrm{O}^{-1}$, respectively, at the $\mathrm{CR}$ site. At the $\mathrm{CF}$ site, DF and WRC averaged 109.7 and $97.1 \mu \mathrm{mol} \mathrm{CO} \mathrm{Cmol} \mathrm{H}_{2} \mathrm{O}^{-1}$, respectively (Figure 2). In general, there was little effect of FVM treatments on iWUE. Only DF (Figure 2c) and WH (Figure 2e) trees growing under T treatment showed lower iWUE than trees growing under O treatment. Overall, iWUE of WRC trees was larger at the CF than at the CR site $(p=0.019)$, and iWUE of DF trees was similar across sites $(p=0.101)$.

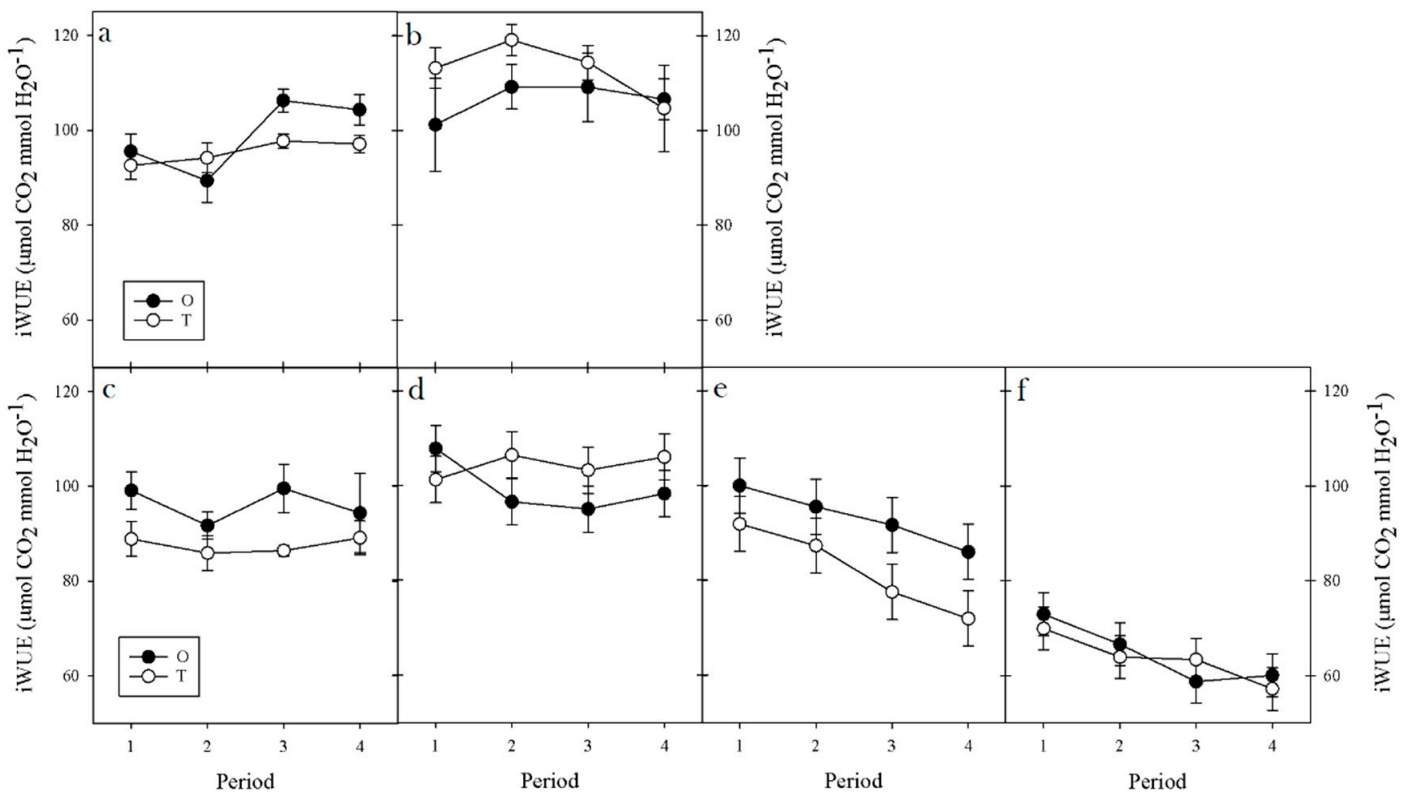

Figure 2. Intrinsic water use efficiency (iWUE, $\mu \mathrm{mol} \mathrm{CO}_{2} \mathrm{mmol} \mathrm{H}_{2} \mathrm{O}^{-1}$ ) for: $(\mathbf{a}, \mathbf{c})$ Douglas-fir; $(\mathbf{b}, \mathbf{d})$ western redcedar; (e) western hemlock; and (f) grand fir trees growing under contrasting vegetation management treatments on a site located in the Cascade Foothills (upper panels) and Coast Range (lower panels) of western Oregon. O: no post-planting vegetation control (open symbol); T: sustained vegetation control during first five years post planting (filled symbol). Error bars represent standard error.

Only DF growing at the CF site showed an interaction effect between treatment and growing period. ( $p=0.015$; Table 2). WH and GF showed a decrease in iWUE as the trees aged, reducing iWUE from period 1 and 4 from about 95.9 to $79.1 \mu \mathrm{mol} \mathrm{CO}_{2} \mathrm{mmol} \mathrm{H}_{2} \mathrm{O}^{-1}$ for $\mathrm{WH}(p=0.005)$, and from about 72.3 to $59.5 \mu \mathrm{mol} \mathrm{CO} \mathrm{mmol} \mathrm{H}_{2} \mathrm{O}^{-1}$ for $\mathrm{GF}(p=0.004)$, respectively.

Table 2. Adjusted $p$-value from the time-series ANOVA for intrinsic water use efficiency (iWUE) of Douglas-fir (DF), western hemlock (WH), western redcedar (WRC), and grand fir (GF) trees growing under contrasting vegetation management treatments on sites located in the Cascade Foothills (CF) and Coast Range (CR) of western Oregon. T: effect of vegetation management treatment; P: effect of growing period; $\mathrm{T} \times \mathrm{P}$ : effect of interaction between treatment and growing period. Bold: result is statistically significant at $p<0.05$.

\begin{tabular}{ccccc}
\hline Site & Species & $\mathbf{T}$ & $\mathbf{P}$ & $\mathbf{T} \times \mathbf{P}$ \\
\hline \multirow{2}{*}{ CF } & DF & 0.229 & $<0.001$ & $\mathbf{0 . 0 1 5}$ \\
& WRC & 0.089 & 0.428 & 0.552 \\
\hline \multirow{4}{*}{ CR } & DF & 0.209 & 0.240 & 0.356 \\
& WH & 0.152 & 0.008 & 0.865 \\
& WRC & 0.402 & 0.527 & 0.114 \\
& GF & 0.763 & 0.006 & 0.711 \\
\hline
\end{tabular}




\subsection{Ring Wood Specific Gravity and Latewood Percent}

For all species, specific gravity of the ring $\left(\mathrm{SG}_{\mathrm{R}}\right)$ (Figure 3a-d) decreased as the tree aged. DF was the only species for which $S G_{R}$ increased again towards the end of the study (Figures 3a and 4a). There was no effect of vegetation management treatment on $\mathrm{SG}_{\mathrm{R}}$ of $\mathrm{DF}, \mathrm{WH}$ and GF. On both sites, WRC growing under sustained vegetation control $(\mathrm{T})$ showed larger $\mathrm{SG}_{\mathrm{R}}$ than under control $(\mathrm{O})$ conditions (Figures $3 c$ and $4 b$ ), but the effect was significant only at the CR site ( $p=0.051$; Table 3 ). For GF younger than seven years, $\mathrm{O}$ trees showed larger $\mathrm{SG}_{\mathrm{R}}$ than $\mathrm{T}$ trees. After that age, there was no difference across treatments (Figure 2d).

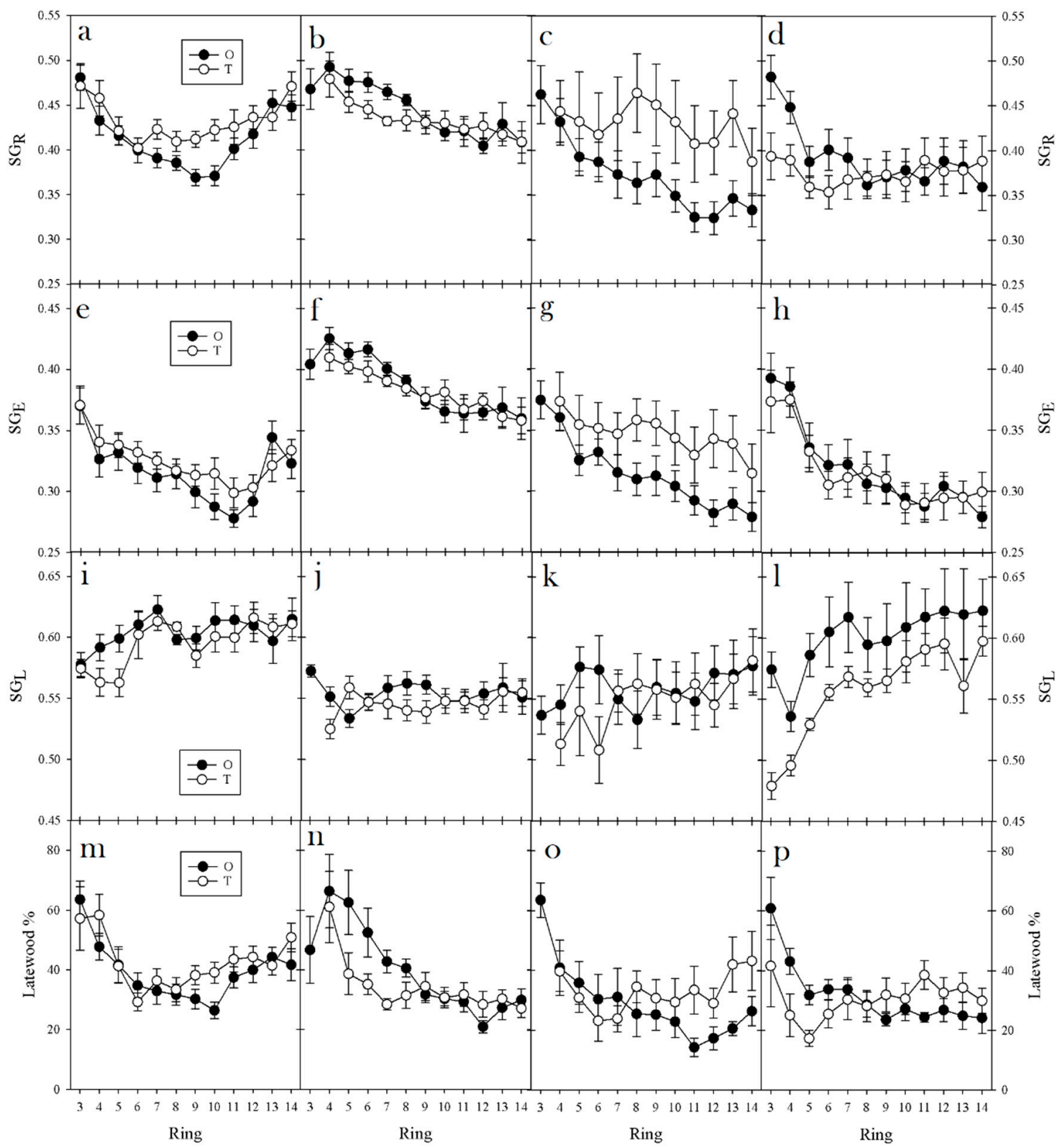

Figure 3. Ring specific gravity $\left(\mathrm{SG}_{\mathrm{R}} ; \mathbf{a}-\mathbf{d}\right)$; earlywood specific gravity $\left(\mathrm{SG}_{\mathrm{E}} ; \mathbf{e}-\mathbf{h}\right)$; latewood specific gravity $\left(\mathrm{SG}_{\mathrm{L}} ; \mathbf{i}-\mathbf{l}\right)$; and latewood percentage $(\mathbf{m}-\mathbf{p})$ for: Douglas-fir $(\mathbf{a}, \mathbf{e}, \mathbf{i}, \mathbf{m})$; western hemlock $(\mathbf{b}, \mathbf{f}, \mathbf{j}, \mathbf{n})$; western redcedar $(\mathbf{c}, \mathbf{g}, \mathbf{k}, \mathbf{o})$; and grand fir $(\mathbf{d}, \mathbf{h}, \mathbf{l}, \mathbf{p})$ trees growing under contrasting vegetation management treatments on a site located in the Coastal Range of western Oregon. O: no post-planting vegetation control (open symbol); T: sustained vegetation control during first five years post planting (filled symbol). Error bars represent standard error. 
Only WRC growing at the CR site (Figure 3g) showed a significant effect of treatment on its earlywood specific gravity ( $\mathrm{SG}_{\mathrm{E}}$; Table 3 ). The treatment trees had a higher $\mathrm{SG}_{\mathrm{E}}$ than the control trees. A similar pattern was observed for WRC at the CF site (Figure $4 \mathrm{~d}$ ), but this effect was not significant $(p=0.13)$. No other species showed effect of treatment on its $\mathrm{SG}_{\mathrm{E}}$ (Figures $3 \mathrm{e}-\mathrm{h}$ and $4 \mathrm{c}, \mathrm{d}$ ).

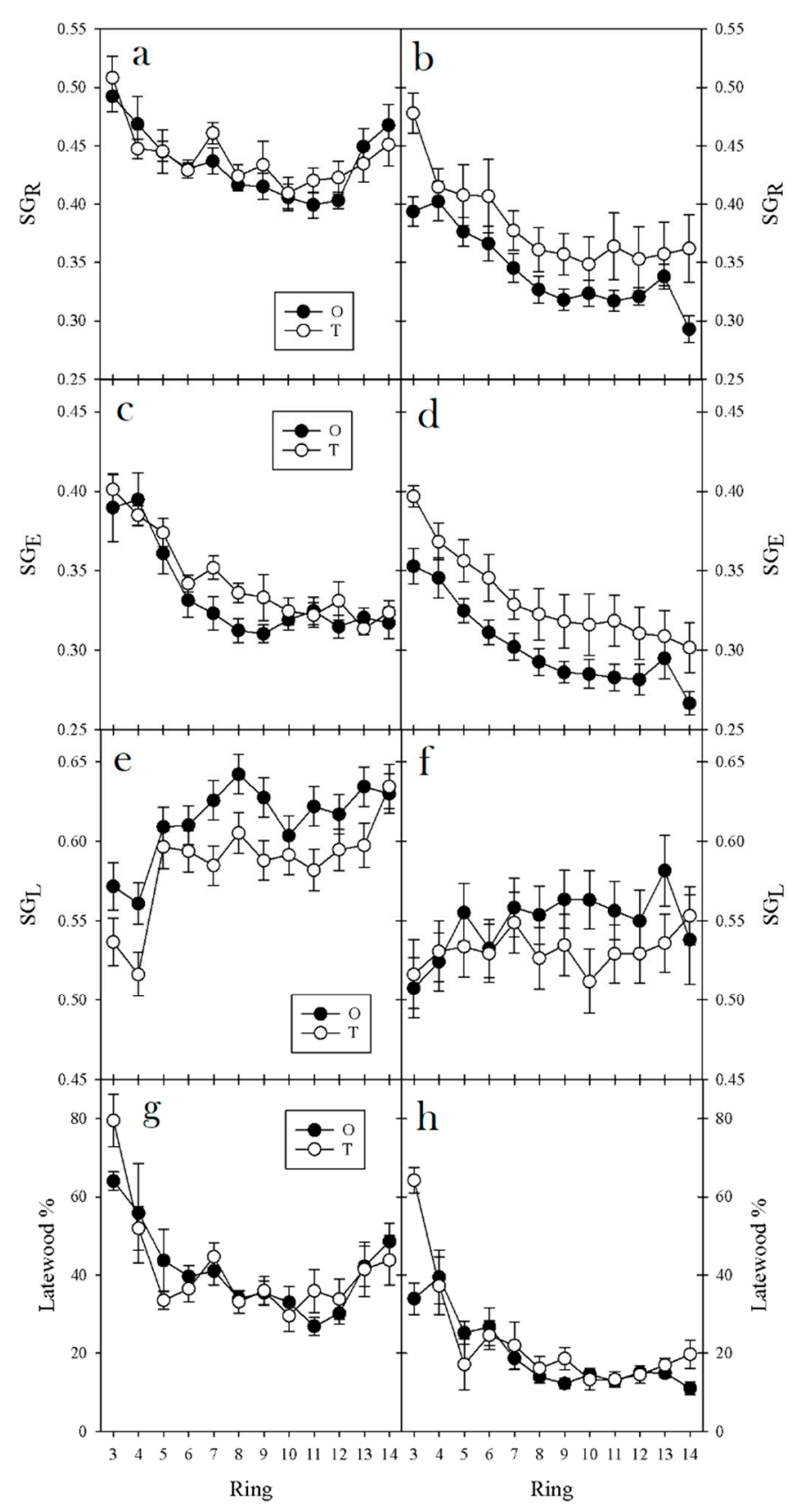

Figure 4. Ring specific gravity (a,b); earlywood specific gravity $(\mathbf{c}, \mathbf{d})$; latewood specific gravity (e,f); and latewood percentage ( $\mathbf{g}, \mathbf{h})$ for: Douglas-fir $(\mathbf{a}, \mathbf{c}, \mathbf{e}, \mathbf{g})$; and western redcedar $(\mathbf{b}, \mathbf{d}, \mathbf{f}, \mathbf{h})$ trees growing under contrasting vegetation management treatments on a site located in the Cascade Foothills of western Oregon. O: no post-planting vegetation control (open symbol); T: sustained vegetation control during first five years post planting (filled symbol). Error bars represent standard error.

Latewood specific gravity $\left(\mathrm{SG}_{\mathrm{L}}\right)$ of all species at both sites was not affected by vegetation management treatments (Figures $3 \mathrm{i}-1$ and $4 \mathrm{e}, \mathrm{f})$. Grand fir at the CR site (Figure 31 ) had a decrease in $\mathrm{SG}_{\mathrm{L}}$ for $\mathrm{T}$ trees, but the difference was non-significant $(p=0.121$; Table 3$)$. 
Table 3. Adjusted $p$-value from the time-series ANOVA test of fixed effects for treatment $(\mathrm{T})$ and the interaction-effect treatment $\times$ ring $(T \times R)$ regarding ring specific gravity $\left(\mathrm{SG}_{\mathrm{R}}\right)$, earlywood specific gravity $\left(\mathrm{SG}_{\mathrm{E}}\right)$, latewood specific gravity $\left(\mathrm{SG}_{\mathrm{L}}\right)$ and latewood percent $(\mathrm{LW} \%)$, for Douglas-fir $(\mathrm{DF})$, western hemlock $(\mathrm{WH})$, western redcedar (WRC), and grand fir (GF) trees growing under contrasting vegetation management treatments on sites located in the Cascade Foothills (CF) and the central Coast Range (CR) of western Oregon. Bold: result is statistically significant at $p<0.05$ or $p<0.01$.

\begin{tabular}{cccccccccc}
\hline & & \multicolumn{2}{c}{$\mathbf{S G}_{\mathbf{R}}$} & \multicolumn{2}{c}{$\mathbf{S G}_{\mathbf{E}}$} & \multicolumn{2}{c}{$\mathbf{S G}_{\mathbf{L}}$} & \multicolumn{2}{c}{$\mathbf{L W} \%$} \\
\hline \multirow{2}{*}{ Site } & Species & $\mathbf{T}$ & $\mathbf{T} \times \mathbf{R}$ & $\mathbf{T}$ & $\mathbf{T} \times \mathbf{R}$ & $\mathbf{T}$ & $\mathbf{T} \times \mathbf{R}$ & $\mathbf{T}$ & $\mathbf{T} \times \mathbf{R}$ \\
\hline \multirow{6}{*}{$\mathrm{CR}$} & DF & 0.119 & 0.122 & 0.515 & 0.349 & 0.272 & 0.387 & 0.347 & 0.288 \\
& WH & 0.557 & 0.288 & 0.795 & 0.455 & 0.329 & $\mathbf{0 . 0 4 0}$ & 0.134 & 0.075 \\
& WRC & 0.051 & 0.644 & $\mathbf{0 . 0 4 4}$ & 0.829 & 0.972 & 0.507 & 0.310 & $\mathbf{0 . 0 0 2}$ \\
& GF & 0.677 & 0.470 & 0.965 & 0.994 & 0.121 & 0.978 & 0.894 & $\mathbf{0 . 0 0 1}$ \\
\hline \multirow{2}{*}{ CF } & DF & 0.378 & 0.698 & 0.229 & 0.104 & $\mathbf{0 . 0 3 4}$ & 0.586 & 0.856 & 0.866 \\
& WRC & 0.390 & 0.354 & 0.130 & 0.795 & 0.145 & 0.765 & 0.798 & 0.224 \\
\hline
\end{tabular}

Across all species, LW\% tends to be larger during early years, reaching somewhat stable values around $30-40 \%$ after ring 7 . Only WRC and GF showed a $\mathrm{T} \times \mathrm{R}$ interaction effect for LW\%. For GF, trees growing under no competition control showed greater $\mathrm{LW} \%$ in the first 5-6 years (Figure 3o). For WRC, trees growing under sustained competition control showed greater LW\% after Year 11 (Figure 3p).

\subsection{Annual Ring Growth}

All species, except WRC at the CF site, showed a significant effect of treatment on its ring area (Table 4), where trees growing under sustained competing vegetation control had a higher ring area than trees growing with no post-planting vegetation control. This response reflects an increase in tree growth with sustained vegetation control. This increase in ring area was due to an increase in either, EW and/or LW area production (Figures 5 and 6).

The response to FVM treatments on EW area was similar to ring area: all species, but WRC at the CF site, showed larger EW area production on trees growing under sustained competing vegetation control when compared with trees growing with no post-planting vegetation control. The length of the response was different for each species. On both sites, DF showed larger EW area until ring 8. At the CR site, WRC and GF showed larger EW area until ring 10, and WH showed increased EW growth until ring 14 (Figure 5).

All species, except WRC at the CF site, showed larger LW area for trees growing under sustained competing vegetation control (Figure 6). The length of the response was species-dependent, but extended longer than for EW area. At both sites, DF showed larger EW area until ring 11. At the CR site, WRC, WH and GF showed larger EW area until ring 13 (Figure 5).

Table 4. Adjusted $p$-value from the ANOVA test of fixed effects for the different sites and species for treatment $(\mathrm{T})$ and the interaction-effect treatment $x$ ring $(T \times R)$ regarding ring area, earlywood (EW) area, and latewood (LW) area for Douglas-fir (DF), western hemlock (WH), western redcedar (WRC), and grand fir (GF) trees growing under contrasting vegetation management treatments on sites located in the Cascade foothills (CF) and central Coast Range (CR) of western Oregon. Bold: result is statistically significant at $p<0.05$.

\begin{tabular}{cccccccc}
\hline & \multicolumn{2}{c}{ Ring Area } & \multicolumn{2}{c}{ EW Area } & \multicolumn{2}{c}{ LW Area } \\
\hline \multirow{2}{*}{ Site } & Species & $\mathbf{T}$ & $\mathbf{T} \times \mathbf{R}$ & $\mathbf{T}$ & $\mathbf{T} \times \mathbf{R}$ & $\mathbf{T}$ & $\mathbf{T} \times \mathbf{R}$ \\
\hline \multirow{4}{*}{ CR } & DF & $\mathbf{0 . 0 1 5}$ & 0.850 & $<\mathbf{0 . 0 0 1}$ & $<\mathbf{0 . 0 0 1}$ & $<\mathbf{0 . 0 0 1}$ & $<\mathbf{0 . 0 0 1}$ \\
& WH & $\mathbf{0 . 0 0 1}$ & $\mathbf{0 . 0 4 6}$ & $\mathbf{0 . 0 0 4}$ & 0.069 & $<0.001$ & $<\mathbf{0 . 0 0 1}$ \\
& WRC & 0.055 & 0.645 & 0.188 & 0.578 & 0.386 & 0.566 \\
& GF & 0.084 & $<\mathbf{0 . 0 0 1}$ & 0.094 & $<\mathbf{0 . 0 0 1}$ & 0.128 & $\mathbf{0 . 0 2 4}$ \\
\hline \multirow{2}{*}{ CF } & DF & $\mathbf{0 . 0 0 9}$ & $\mathbf{0 . 0 1 0}$ & $\mathbf{0 . 0 1 2}$ & 0.265 & $<\mathbf{0 . 0 0 1}$ & $<\mathbf{0 . 0 0 1}$ \\
& WRC & 0.964 & 0.433 & 0.979 & 0.773 & 0.344 & 0.973 \\
\hline
\end{tabular}




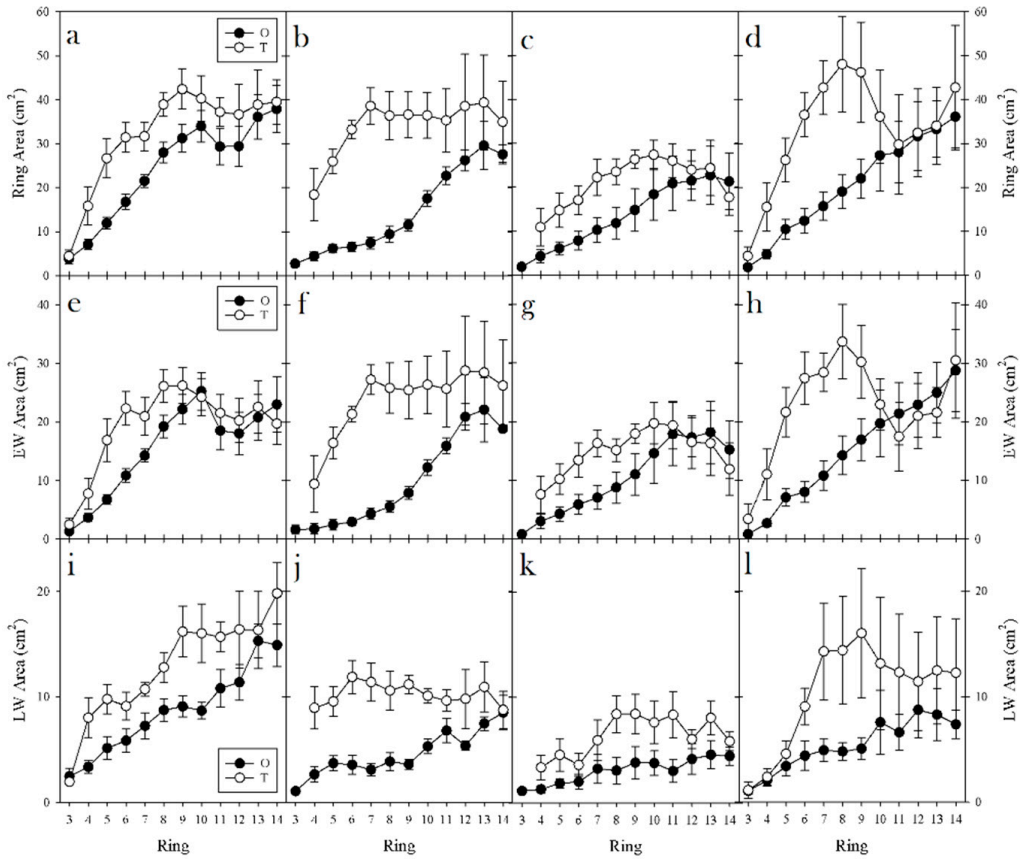

Figure 5. Ring area (a-d); earlywood area (e-h); and latewood area (i-1) for: Douglas-fir (a,e,i); western hemlock $(\mathbf{b}, \mathbf{f}, \mathbf{j})$; western redcedar $(\mathbf{c}, \mathbf{g}, \mathbf{k})$; and grand fir $(\mathbf{d}, \mathbf{h}, \mathbf{l})$ trees growing under contrasting vegetation management treatments on a site located in the Coastal Range of western Oregon. O: no post-planting vegetation control (open symbol); T: sustained vegetation control during first five years post planting (filled symbol). Error bars represent standard error.

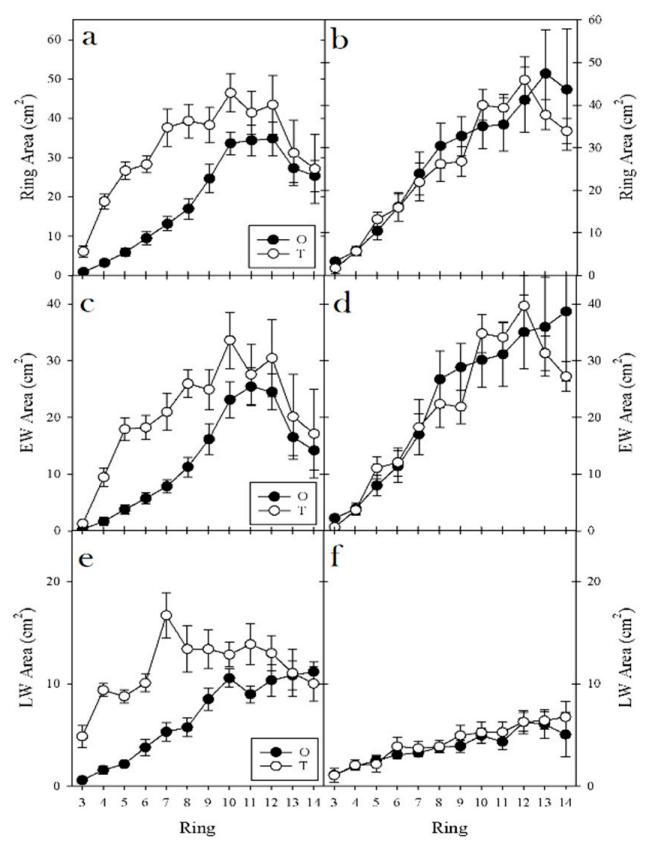

Figure 6. Ring area $(\mathbf{a}, \mathbf{b})$; earlywood area $(\mathbf{c}, \mathbf{d})$; and latewood area $(\mathbf{e}, \mathbf{f})$ for: Douglas-fir $(\mathbf{a}, \mathbf{c}, \mathbf{e})$; and western redcedar $(\mathbf{b}, \mathbf{d}, \mathbf{f})$ trees growing under contrasting vegetation management treatments on a site located in the Cascade Foothills of western Oregon. O: no post-planting vegetation control (open symbol); T: sustained vegetation control during first five years post planting (filled symbol). Error bars represent standard error. 


\subsection{Whole-Tree Wood Properties and Ring Growth}

Overall, WH showed larger whole-core area-weighted $\mathrm{SG}_{\mathrm{R}}$, followed by DF, WRC and GF, averaging $0.429,0.414,0.387$ and 0.367 , respectively, at the CR site. At the CF site, DF and WRC averaged 0.422 and 0.333 , respectively (Table 5). There was no effect of FVM treatments on whole-core area-weighted $\mathrm{SG}_{\mathrm{R}}$. Only a non-significant increment in whole-core area-weighted $\mathrm{SG}_{\mathrm{E}}$ was observed for DF and WRC growing at the CF site ( $p=0.063$ and 0.097 , respectively). Only DF at the CF site had a significant effect of treatment on its whole-core area-weighted $\mathrm{SG}_{\mathrm{L}}$ (Table 5), with trees growing under sustained competing vegetation control having a lower $\mathrm{SG}_{\mathrm{L}}$ than control trees. This change in $\mathrm{SG}_{\mathrm{L}}$ did not change $\mathrm{SG}_{\mathrm{R}}$.

Table 5. Least Square Means for whole-core area-weighted wood specific gravity for Douglas-fir (DF), western hemlock (WH), western redcedar (WRC), and grand fir (GF) trees growing under contrasting vegetation management treatments on sites located in the Cascade foothills $(\mathrm{CF})$ and the central Coast Range (CR) of western Oregon.

\begin{tabular}{ccccccccccc}
\hline & & \multicolumn{3}{c}{$\mathbf{S G}_{\mathbf{R}}$} & \multicolumn{3}{c}{$\mathbf{S G}_{\mathbf{E}}$} & \multicolumn{3}{c}{$\mathbf{S G}_{\mathbf{L}}$} \\
\hline Site & Species & $\mathbf{O}$ & $\mathbf{T}$ & $\boldsymbol{p}>\mathbf{F}$ & $\mathbf{O}$ & $\mathbf{T}$ & $\boldsymbol{p}>\mathbf{F}$ & $\mathbf{O}$ & $\mathbf{T}$ & $\boldsymbol{p}>\mathbf{F}$ \\
\hline \multirow{2}{*}{ CF } & DF & 0.419 & 0.425 & 0.506 & 0.319 & 0.333 & 0.063 & 0.619 & 0.592 & 0.030 \\
& WRC & 0.326 & 0.341 & 0.189 & 0.287 & 0.305 & 0.097 & 0.553 & 0.523 & 0.107 \\
\hline \multirow{4}{*}{ CR } & DF & 0.403 & 0.424 & 0.110 & 0.305 & 0.319 & 0.174 & 0.605 & 0.596 & 0.369 \\
& WH & 0.427 & 0.430 & 0.669 & 0.373 & 0.381 & 0.253 & 0.550 & 0.542 & 0.323 \\
& WRC & 0.354 & 0.418 & 0.176 & 0.305 & 0.337 & 0.134 & 0.569 & 0.540 & 0.200 \\
& GF & 0.360 & 0.385 & 0.199 & 0.299 & 0.322 & 0.110 & 0.600 & 0.566 & 0.329 \\
\hline
\end{tabular}

O: no post-planting vegetation control; T: sustained vegetation control during first 5 years post planting.

For all species, except WRC, FVM treatments had an effect on whole-tree total ring area, with the trees growing under sustained competing vegetation control having a larger ring area than control trees (Table 6). For WH at the CR site, and DF at the CF site, there was also a significant increase in whole-tree EW area for treatment trees. For GF at the CR site there was a marginal effect on EW area $(p=0.074)$. LW area also increased for DF and WH trees growing under sustained competing vegetation control. For WRC at the CR site, there was a marginal effect on LW area $(p=0.083)$. Only WRC growing at the CF site showed a significant effect of FVM treatments on whole-tree LW\% $(p=0.058)$. For WRC growing at the CF site, even though there was an $83 \%$ increase in LW area, the difference was not significant $(p=0.17)$.

Table 6. Least Square Means for whole-tree total ring area, earlywood area (EW), latewood area (LW) and latewood percentage (LW\%) for Douglas-fir (DF), western hemlock (WH), western redcedar (WRC), and grand fir (GF) trees growing under contrasting vegetation management treatments on sites located in the Cascade foothills (CF) and the central Coast Range (CR) of western Oregon. Bold: result is statistically significant at $p<0.05$ or $p<0.01$.

\begin{tabular}{cccccccccccccc}
\hline & & \multicolumn{4}{c}{ Ring Area $\left(\mathbf{c m}^{2}\right)$} & \multicolumn{3}{c}{ EW Area $\left(\mathbf{c m}^{\mathbf{2}}\right)$} & \multicolumn{3}{c}{ LW Area $\left(\mathbf{c m}^{\mathbf{2}}\right)$} & \multicolumn{3}{c}{ LW\% } \\
\hline Site & Species & $\mathbf{O}$ & $\mathbf{T}$ & $\boldsymbol{p}>\mathbf{F}$ & $\mathbf{O}$ & $\mathbf{T}$ & $\boldsymbol{p}>\mathbf{F}$ & $\mathbf{O}$ & $\mathbf{T}$ & $\boldsymbol{p}>\mathbf{F}$ & $\mathbf{O}$ & $\mathbf{T}$ & $\boldsymbol{p}>\mathbf{F}$ \\
\hline \multirow{4}{*}{ CR } & DF & 276.6 & 377.9 & 0.060 & 181.4 & 228.1 & 0.177 & $\mathbf{9 5 . 2}$ & $\mathbf{1 4 9 . 9}$ & $\mathbf{0 . 0 3 7}$ & 34.5 & 39.8 & 0.172 \\
& WH & $\mathbf{1 4 1 . 9}$ & 342.7 & $\mathbf{0 . 0 1 3}$ & $\mathbf{9 5 . 3}$ & $\mathbf{2 3 9 . 5}$ & $\mathbf{0 . 0 2 3}$ & $\mathbf{4 6 . 5}$ & $\mathbf{1 0 3 . 3}$ & $\mathbf{0 . 0 0 4}$ & 32.2 & 31.7 & 0.799 \\
& WRC & 195.1 & 218.4 & 0.684 & 155.2 & 153.7 & 0.975 & $\mathbf{3 8 . 4}$ & $\mathbf{6 6 . 1}$ & $\mathbf{0 . 0 3 6}$ & 21.7 & 31.7 & 0.153 \\
& GF & 227.0 & 448.2 & 0.061 & 166.7 & 336.4 & 0.074 & 60.3 & 111.7 & 0.147 & 26.7 & 29.6 & 0.348 \\
\hline \multirow{2}{*}{ CF } & DF & $\mathbf{2 2 8 . 9}$ & $\mathbf{3 4 3 . 5}$ & $\mathbf{0 . 0 1 5}$ & 150.0 & 222.3 & 0.057 & $\mathbf{7 8 . 9}$ & $\mathbf{1 2 3 . 4}$ & $\mathbf{0 . 0 1 2}$ & 35.1 & 36.6 & 0.649 \\
& WRC & 275.0 & 265.4 & 0.839 & 218.5 & 218.9 & 0.989 & 38.1 & 44.5 & 0.321 & 14.6 & 17.8 & 0.142 \\
\hline
\end{tabular}

O: no post-planting vegetation control; T: sustained vegetation control during first five years post planting. 


\section{Discussion}

An increase in iWUE can be explained by a higher carbon assimilation rate, a lower stomatal conductance, or a combination of both. When a tree experiences drought and closes its stomata to limit moisture evaporation, it will also limit its $\mathrm{CO}_{2}$ uptake and decrease the carbon assimilation rate [13]. A lower stomatal conductance, due to closed stomata, will increase the iWUE, but a lower carbon assimilation rate, also due to closing stomata, will decrease the iWUE. It is difficult to discern whether a difference in stomatal conductance or difference in assimilation rate of carbon has the largest effect on the iWUE. Recent literature suggests that the effect of lower stomatal conductance is greater than the effect of lower assimilation rate [31,32] and thus iWUE is increased by reducing stomatal opening. We observed little effect of FVM treatments on iWUE. Only DF and WH trees growing under sustained competing vegetation control showed a reduced iWUE. At age five years, DF, WH, WRC and GF control trees at the CR site, had mean heights of 3.0, 2.3, 1.3 and $1.8 \mathrm{~m}$, respectively, while the heights of DF and WRC at the CF site, were 2.3 and $1.3 \mathrm{~m}$ (data not shown), indicating that WRC and GF trees were shorter and, therefore, had lower leaf area and water demand. Even though it has been demonstrated that VM increases soil moisture and reduces seedling water stress on planted Douglas-fir [33,34] it is possible that the level of water stress experienced by GF and WRC control trees during the first five growing seasons was not strong enough to have a significant effect on iWUE, or that the effect on stomatal conductance was similar to the effect on the carbon assimilation rate, thus cancelling each other out.

DF trees showed no differences in iWUE across sites, while WRC trees showed lower iWUE at the CR site compared to the CF site. This may indicate that WRC trees at the CF site experienced more water stress than the trees at the CR site. Supporting evidence on differential water stress was reported by McCulloh et al. (2014) [35], who demonstrated that WRC trees are more vulnerable to xylem cavitation than DF trees. In addition, the amount of precipitation received at both sites also support our findings: between years 2000 and 2010, the CR site received an average of $1619 \mathrm{~mm}_{\text {year }}{ }^{-1}$ while the CF sites received an average of $1346 \mathrm{~mm}_{\text {year }}{ }^{-1}$, while soil water holding capacity was similar across sites. The CF site experienced a severe drought during growing season 2 (year 2001), while the CF site had a lower PDSI during growing season 1, 2 and 3 (years 2001, 2002 and 2003).

Trees growing under sustained competing vegetation control had a significantly larger ring area than the control trees for all species but WRC (Table 6). Even though there was a 60\% increase in ring area for WRC at the $\mathrm{CF}$ site, that difference was not significant. For DF and $\mathrm{WH}$, the ring area increment was due to an increase in EW and LW area with FVM treatment. However, there was no significant increase in whole-tree LW\% for DF, WH and GF, so the increase in EW and LW area was likely to be of similar proportion, thus having no effect on LW\%. Only WRC a showed a significant increase in LW\%. This response seems to be an effect of extended LW production for FVM WRC trees at the CF site. An indeterminate species, such as WRC, has the ability to continue growing when environmental conditions are favorable [36], and increased soil moisture availability may have extended the WRC growing season at the CF site. This result is in agreement with our finding for iWUE, where WRC trees growing at the CF site had larger iWUE than at the CR site.

For the whole-core area-weighted specific gravity analysis, only DF at the CF site had a significant treatment effect for $\mathrm{SG}_{\mathrm{L}}$, but the decrease in $\mathrm{SG}_{\mathrm{L}}$ was not reflected in a decrease in $\mathrm{SG}_{\mathrm{R}}$. No other species had any effect on its whole-tree wood properties with sustained FVM treatment. These results indicate that the positive effect of FVM treatments on radial growth are not detrimental to wood properties. For the same plots used in this study, Flamenco et al. (2018) [21] reported no effect of FVM on the relationship between DBH and stemwood biomass. The authors concluded that reducing competing vegetation cover during the early stages of stand development positively impacted tree growth, increasing stand biomass at age 16 years.

The positive growth response we observed has been reported in earlier studies on PNW species [37]. Slesak et al. (2016) [38] found that the application of vegetation control was effective at increasing Douglas-fir tree growth, with $45 \%$ to $180 \%$ increase of stand volume after 10 years of 
growth. Rose et al. (2006) [8] found Douglas-fir growth increase ranging from $63 \%$ to $355 \%$, depending on site, after 12 years. Wagner and Robinson (2006) [39] compared the 10-year growth response in four northern conifers and found a growth increase ranging from $117 \%$ to $343 \%$, depending on species, after five years of vegetation management. They stated that stand volume increased with number of years of sustained vegetation management, and that the relationship varied among conifer species. Antony et al. (2011) [40] reported a similar growth response in loblolly pine (Pinus taeda L.), while Watt et al. (2005) [41] also reported a positive response in radiata pine (Pinus radiata D. Don) grown in New Zealand.

The radial development of the specific gravity of the ring, for all four species, followed recognized trends. The $\mathrm{SG}_{\mathrm{R}}$ of DF decreased and then started to increase (at different ages), at both sites, while the $\mathrm{SG}_{\mathrm{R}}$ of $\mathrm{WH}, \mathrm{WCR}$, and GF all decreased. These trends can also be found in the juvenile wood of several other conifers, for example Norway spruce (Picea abies (L.) H. Karst.) and lodgepole pine (Pinus contorta Douglas) [20,42]. Jozsa and Middleton (1994) [43] summarized ring specific gravity at breast height from pith-to-bark of several conifer species, including those in this study, and reported the same radial development for $\mathrm{SG}_{\mathrm{R}}$.

Bassett (1964) [44] found that diameter growth cessation depended on soil moisture and evaporation demand. When there was no moisture limitation, diameter growth continues until late in the season when other factors (temperature or photoperiod) trigger cessation. Gonzalez-Benecke et al. (2010) [19] found similar results for loblolly pine and concluded that there was a strong and positive relationship between high soil water availability and gain in ring SG and LW\%. During first five growing seasons, competing vegetation cover percent was much larger at the plots without post-planting vegetation control [7], so it can be assumed that in those plots the trees had less soil moisture available due to more competition for water, and thus may have had a shorter latewood growing season due to water limitations. Clark et al. (2004) [45] found that vegetation control did not significantly affect SG, but did increase basal area and the diameter of the juvenile core in 12-year-old loblolly pine and the results of this study are consistent with their findings. On determinate species (DF, WH, and GF), reducing competing vegetation cover increased growth but did not affected wood properties. On the indeterminate species (WRC) reducing competing vegetation cover increased growth and increased SG at the site with larger abundance of shrubs and trees in the understory and midstory. For the same study plots analyzed in this study, Flamenco et al. (2018) [21] reported that, at age 16 years, understory and midstory vegetation accounted for $46-50 \%$ of total aboveground ecosystem biomass of WH and GF control plots, while for WRC, competing vegetation accounted for $72 \%$ of total aboveground ecosystem biomass. The large presence of competing vegetation on $\mathrm{C}$ plots was associated with reduced tree growth, but not reflected in xylem $\delta^{13} \mathrm{C}$. We observed a trend towards no change in iWUE or even reduced iWUE on treated plots with determinate species. On the other hand, there was a trend towards increased iWUE on treated plots with WRC (indeterminate). These results indicate that responses to soil water availability are species-specific and may integrate effects of allocation, vulnerability to xylem cavitation and stomatal conductance.

Competing vegetation management in plantations based on common PNW species produced a positive growth response on both sites, while measured wood property attributes $\left(\mathrm{SG}_{\mathrm{R}}, \mathrm{SG}_{\mathrm{E}}, \mathrm{SG}_{\mathrm{L}}\right.$ and $\mathrm{LW} \%$ ) were largely unchanged. The growth response is such that trees growing on treated sites can be expected to reach merchantable size at a younger age. While this is an important outcome, such strategies should be practiced with caution if wood quality impacts are considered. Even though wood properties are largely unchanged, trees harvested at a younger age have a higher proportion of low quality corewood with low density, stiffness and stability. This is of particular importance if the wood was going to be used for structural purposes.

\section{Conclusions}

The results from this research show that, for all four conifer species studied, trees growing under sustained removal of competing vegetation produced large radial stem growth and showed a limited 
effect on plant water status and wood specific gravity, indicating that intensive forest vegetation management can increase volume growth without compromising the wood properties of the trees. However, if harvested at a target diameter, these trees will have a larger proportion of low quality corewood compared to trees from conventionally managed stands.

Author Contributions: C.A.G.-B. and L.R.S. conceived and designed the experiments. J.A. analyzed the data and wrote the paper.

Funding: This research was supported by the Forest Engineering, Resources and Management Department and the Vegetation Management Research Cooperative at Oregon State University.

Acknowledgments: Special thanks go to Herman Flamenco and Maxwell Wightman for their help with data collection and Joe Dahlen (UGA) for assistance with sample preparation and analysis.

Conflicts of Interest: The authors declare no conflict of interest and the founding sponsors had no role in the design of the study; in the collection, analyses, or interpretation of data; in the writing of the manuscript, and in the decision to publish the results.

\section{References}

1. Franklin, J.E.; Spies, T.A.; Swanson, F.J. Setting the stage: Vegetation ecology and dynamics. In People, Forests, and Change: Lessons from the Pacific Northwest; Olson, D., Van Horne, B., Eds.; Island Press: Washington, DC, USA, 2017; pp. 16-32.

2. Farr, W.; Harris, A. Site index of Sitka spruce along the Pacific coast related to latitude and temperatures. For. Sci. 1979, 25, 145-153.

3. Jensen, E.C. Trees to Know in Oregon; Oregon State University Extension Service: Corvallis, OR, USA, 2010.

4. Chen, F.-H. Effects of Weed Control on Vegetation Dynamics in Pacific Northwest Conifer Plantations; Oregon State University: Corvallis, OR, USA, 2004.

5. Ammer, C.; Balandier, P.; Bentsen, N.S.; Coll, L.; Löf, M. Forest vegetation management under debate: An introduction. Eur. J. For. Res. 2011, 130, 1-5. [CrossRef]

6. Ketchum, J.S.; Newton, M.; Rose, R. Vegetation management: One of the most imporatnt tools in foresty. West. For. 1999, 44, 1, 4, 8 .

7. Maguire, D.A.; Mainwaring, D.B.; Rose, R.; Garber, S.M.; Dinger, E.J. Response of coastal Douglas-fir and competing vegetation to repeated and delayed weed control treatments during early plantation development. Can. J. For. Res. 2009, 39, 1208-1219. [CrossRef]

8. Rose, R.; Rosner, L.S.; Ketchum, J.S. Twelfth-year response of Douglas-fir to area of weed control and herbaceous versus woody weed control treatments. Can. J. For. Res. 2006, 36, 2464-2473. [CrossRef]

9. Boyd, R.S.; Freeman, J.D.; Miller, J.H.; Edwards, M.B. Forest herbicide influences on floristic diversity seven years after broadcast pine release treatments in central Georgia, USA. New For. 1995, 10, 17-37.

10. Boateng, J.O.; Haessler, S.; Bedford, L. Boreal plant community diversity 10 years after glyphosphate treatment. West. J. Appl. For. 2000, 15, 15-26.

11. Dinger, E.J.; Rose, R. Initial fall-spring vegetation management regimes improve moisture conditions and maximise third-year Douglas-fir seedling growth in a Pacific Northwest plantation. J. For. Sci. 2010, 40, 199-209.

12. Goracke, H.S.R. Temporal Effect of Vegetation Management on Growth and Wood Quality of Confiers in a Western Oregon Plantation; Oregon State University: Corvallis, OR, USA, 2010.

13. Osakabe, Y.; Osakabe, K.; Shinozaki, K.; Tran, L.-S.P. Response of plants to water stress. Front. Plant Sci. 2014, 5, 86. [CrossRef] [PubMed]

14. Pallardy, S.G. Chapter 5-Photosynthesis. In Physiology of Woody Plants; Academic Press: San Diego, CA, USA, 2008; pp. 107-167.

15. Domec, J.-C.; Gartner, B.L. How do water transport and water storage differ in coniferous earlywood and latewood? J. Exp. Bot. 2002, 53, 2369-2379. [CrossRef] [PubMed]

16. Speer, J.H. Fundamentals of Tree-Ring Research; University of Arizona Press: Tucson, AZ, USA, 2011; Volume 26, ISBN 0816526842.

17. Warren, W.G. The contribution of earlywood and latewood specific gravities to overall wood specific gravity. Wood Fiber Sci. 1979, 11, 127-135. 
18. Strause, D.A. Specific Gravity and per Cent Summerwood Variation in a Young Douglas-Fir Clone and Use of Uniformity Trial in Predicting Specific Gravity from Increment Cores. Master's Thesis, Oregon State College, Corvallis, OR, USA, 1959.

19. Gonzalez-Benecke, C.A.; Martin, T.A.; Clark, A.; Peter, G.F. Water availability and genetic effects on wood properties of loblolly pine (Pinus taeda). Can. J. For. Res. 2010, 40, 2265-2277. [CrossRef]

20. Barnett, J.; Jeronimidis, G. (Eds.) Wood Quality and its Biological Basis; John Wiley \& Sons: Hoboken, NJ, USA, 2003; ISBN 0849328195.

21. Flamenco, H.N.; Gonzalez-Benecke, C.A.; Wightman, M.G. Long-term effects of vegetation management on biomass stock of four coniferous species in the Pacific Northwest United States. For. Ecol. Manag. 2018, in press.

22. Brienen, R.J.W.; Wanek, W.; Hietz, P. Stable carbon isotopes in tree rings indicate improved water use efficiency and drought responses of a tropical dry forest tree species. Trees 2010, 25, 103-113. [CrossRef]

23. Keeling, R.F.; Piper, S.C.; Bollenbacher, A.F.; Walker, S.J. Monthly Atmospheric 13C/12C Isotopic Ratios for 11 SIO Stations; Oak Ridge National Lab. (ORNL): Oak Ridge, TN, USA, 2010.

24. Tans, P. Trends in Atmospheric Carbon Dioxide. Available online: www.esrl.noaa.gov/gmd/ccgg/trends / (accessed on 14 August 2017).

25. McCarroll, D.; Loader, N.J. Stable isotopes in tree rings. Quat. Sci. Rev. 2004, 23, 771-801. [CrossRef]

26. Jordan, L.; Clark, A.; Schimleck, L.R.; Hall, D.B.; Daniels, R.F. Regional variation in wood specific gravity of planted loblolly pine in the United States. Can. J. For. Res. 2008, 38, 698-710. [CrossRef]

27. Jordan, L.; Schimleck, L.R.; Clark, A.; Hall, D.B.; Daniels, R.F. Estimating optimum sampling size to determine weighted core specific gravity of planted loblolly pine. Can. J. For. Res. 2007, 37, 2242-2249. [CrossRef]

28. Palmer, W.C. Meteorological Drought. Res. Pap. No. 45; US Department of Commerce Weather Bureau: Washington, DC, USA, 1965.

29. Abatzoglou, J.T.; McEvoy, D.J.; Redmond, K.T. The West Wide Drought Tracker: Drought Monitoring at Fine Spatial Scales. Bull. Am. Meteorol. Soc. 2017, 98, 1815-1820. [CrossRef]

30. Orhan, H.; Eyduran, E.; Akbaş, Y. Defining the best covariance structure for sequential variation on live weights of anatolian merinos male lambs. J. Anim. Plant Sci. 2010, 20, 158-163.

31. Nobel, P.S.; Nobel, P.S. Chapter 8-Leaves and Fluxes. In Physicochemical and Environmental Plant Physiology; Academic Press: Cambridge, MA, USA, 2009; pp. 364-437. ISBN 9780123741431.

32. De Almeida Silva, M.; Jifon, J.L.; dos Santos, C.M.; Jadoski, C.J.; da Silva, J.A.G. Photosynthetic capacity and water use efficiency in sugarcane genotypes subject to water deficit during early growth phase. Braz. Arch. Biol. Technol. 2013, 56, 735-748. [CrossRef]

33. Dinger, E.J.; Rose, R. The integration of soil moisture, xylem water potential, and fall-spring herbicide treatments to achieve the maximum growth response in newly planted Douglas-fir seedlings. Can. J. For. Res. 2009, 39, 1401-1414. [CrossRef]

34. Gonzalez-Benecke, C.A.; Dinger, E.J. Use of water stress integral to evaluate relationships between soil moisture, plant water stress and stand productivity in young Douglas-fir trees. New For. 2018, in press.

35. Mcculloh, K.A.; Johnson, D.M.; Meinzer, F.C.; Woodruff, D.R. The dynamic pipeline: Hydraulic capacitance and xylem hydraulic safety in four tall conifer species. Plant Cell Environ. 2014, 37, 1171-1183. [CrossRef] [PubMed]

36. Walters, J.; Soos, J. Shoot growth patterns of some British Columbia conifers. For. Sci. 1963, 9, 83-85.

37. Miller, J.H.; Zutter, B.R.; Newbold, R.A.; Edwards, M.B.; Zedaker, S.M. Growth and yield relative to competition for loblolly pine plantations to midrotation-Southeastern United States regional study. South. J. Appl. For. 2003, 27, 237-252.

38. Slesak, R.A.; Harrington, T.B.; Peter, D.H.; DeBruler, D.G.; Schoenholtz, S.H.; Strahm, B.D. Effects of intensive management practices on 10-year Douglas-fir growth, soil nutrient pools, and vegetation communities in the Pacific Northwest, USA. For. Ecol. Manag. 2016, 365, 22-33. [CrossRef]

39. Wagner, R.G.; Robinson, A.P. Critical period of interspecific competition for four northern conifers: 10-year growth response and associated vegetation dynamics. Can. J. For. Res. 2006, 36, 2474-2485. [CrossRef]

40. Antony, F.; Schimleck, L.R.; Jordan, L.; Clark, A.; Daniels, R.F. Effect of early age woody and herbaceous competition control on wood properties of loblolly pine. Fuel Energy Abstr. 2011, 262, 1639-1647. [CrossRef] 
41. Watt, M.S.; Downes, G.M.; Whitehead, D.; Mason, E.G.; Richardson, B.; Grace, J.C.; Moore, J.R. Wood properties of juvenile Pinus radiata growing in the presence and absence of competing understory vegetation at a dryland site. Trees-Struct. Funct. 2005, 19, 580-586. [CrossRef]

42. Zobel, B.; Sprague, J. Juvenile Wood in Trees; Timell, T.E., Ed.; Springer: Berlin/Heidelberg, Germany, 1998; ISBN 9783642721281.

43. Jozsa, L.A.; Middleton, G.R. A Discussion of Wood Quality Attributes and Their Practical Implications; Forintek Canada Corporation: Vancouver, BC, Canada, 1994.

44. Bassett, J.R. Diameter growth of loblolly pine trees as affected by soil-moisture availability. Res. Pap. 1964, 7, 9.

45. Clark, A.; Borders, B.E.; Daniels, R.F. Impact of vegetation control and annual fertilization on properties of loblolly pine wood at age 12. For. Prod. J. 2004, 54, 90-96.

(C) 2018 by the authors. Licensee MDPI, Basel, Switzerland. This article is an open access article distributed under the terms and conditions of the Creative Commons Attribution (CC BY) license (http:/ / creativecommons.org/licenses/by/4.0/). 